\title{
Primary production of benthic microalgae in an intertidal sand flat of the Ria de Arosa, NW Spain
}

\author{
Manuel Varela \& Ernesto Penas
}

Instituto Espan̄ol de Oceanografía, Apartado No. 130, La Coruña, Spain

\begin{abstract}
Primary production of benthic microalgae was studied in an intertidal sand flat in the Ria de Arosa (NW Spain), where an intensive bivalve aquaculture takes place. Active and degraded pigments, organic matter, and vertical migration of algae were also studied. Total annual production, combining high and low tide values, reached $79 \mathrm{gC} \mathrm{m}^{-2}$, while water column production in the same place was only $6 \mathrm{gC} \mathrm{m}^{-2}$, which suggests that resuspended benthic microalgae can be a major food source for bivalves. Year-round production showed no clear seasonal peaks, probably due to intense sediment disturbance by culturing manipulations, and to high detrital supply: 94 to $98 \%$ of organic matter in the sediment is allochtonous non-living material.
\end{abstract}

\section{INTRODUCTION}

The Ria de Arosa (Fig. 1) is a fjord-like bay in northwestern Spain, where intense multidisciplinary research has been carried out in the past $5 \mathrm{yr}$, due to its high ecological interest (Tenore \& Gonzalez 1975, Tenore et al. 1982, Penas 1984) as well as its importance in shellfishing, especially bivalve cultures. Clams (Venerupis pullastra Montagu, V. decussata Linné) and cockles (Cerastoderma edule Linné) are cultivated in extensive intertidal and subtidal sand flats. These cultures (bivalve seeds are spread on the sediment each winter, after the autumn harvest) reach very high densities (up to $10 \mathrm{~kg}$ total weight $\mathrm{m}^{-2}$ for $C$. edule, $350 \mathrm{~g}$ organic matter $\mathrm{m}^{-2}$ ) and this suggests the need of a large food supply for filter feeders in those areas. While phytoplankton production has been investigated (Nunes et al. 1984, Varela et al. 1984) no attention at all has been paid to the benthic microflora production in the sand flats, nor to its importance as food source for bivalves. As can be expected from evidence found elsewhere (Wetzel 1964, Hargrave 1969, Leach 1970, Cadee \& Hegeman 1974, Matheke \& Horner 1974, Joint 1978) microbenthic primary production can be several times higher than that of phytoplankton, and the microbenthic cells can be, by resuspension, a major food source for bivalves.

We have focused our work on the study of primary production of benthic microalgae in an intertidal sand flat near Carril (Fig. 1), an area cultivated for cockles, during a complete year cycle. The study comprised in situ primary production measurements in different conditions (high tide and exposed conditions), as well as biomass measurements, spatial heterogeneity and vertical migration of microalgae. Various factors related to primary production were also measured. Phytoplankton primary production was measured simultaneously with benthic incubations, so that planktonic and benthic productions could be compared.

\section{MATERIALS AND METHODS}

The area sampled (Fig. 1) is an intertidal sand flat, where an extensive culture of cockles (Cerastoderma edule Linné) takes place. Samples were taken, and in situ incubations carried out, monthly over 14 mo from October 1980 to November 1981

A wide range of sample sizes and incubation times have been used by different authors to measure microbenthic primary production: 2 to $50 \mathrm{~cm}^{2}$ and 2 to $6 \mathrm{~h}$ respectively (Leach 1970, Stanley 1971, Marshall et al. 1973, Cadee \& Hegeman 1974, Matheke \& Horner 1974, Van Raalte et al. 1974, Joint 1978, Riznyk et al. 1978). The results obtained are very variable, and no attempt has been made, to our knowledge, to standardize methods. Thus, we have attempted to find the minimal sample size and incubation time appropriate to our case, in order to minimize experimental errors and time waste. According to our results, the incuba- 
tions should take around $2 \mathrm{~h}$ and the $13 \mathrm{~cm}^{2}$ corer area is the most suitable in this case.

Separate measurements of carbon assimilation were made each month under high (flooded) and low (exposed) tide conditions, in order to investigate the influence of tidal level on primary production, and to have better estimates of integrated production over daily periods.

Samples for low-tide incubations were taken just after the sediment was exposed to the air by the ebb tide. Intact sediment samples were obtained by acrylic plastic corers ( $4 \mathrm{~cm}$ I.D., $8 \mathrm{~cm}$ high, $13 \mathrm{~cm}^{2}$ area) gently pushed $3 \mathrm{~cm}$ into the sediment. After removal, the corers were stopped at the bottom, leaving the top $3 \mathrm{~cm}$ of sediment enclosed in the corer. These were incubated with $2.5 \mu \mathrm{Ci}$ of ${ }^{14} \mathrm{C}$ (as $\mathrm{NaHCO}_{3}$ ) diluted in $20 \mathrm{ml}$ of seawater, previously filtered in situ by the method devised by Maciolek (1963). The water was added gently, to avoid disturbance of the sample. Three replicate light samples and 1 dark control were incubated for $2 \mathrm{~h}$, from $1100 \mathrm{~h}$ to $1300 \mathrm{~h}$ approximately, choosing for sampling those days in which low tide occurred at noon, in order to standardize the incubations for the yearly sampling.

Samples were fixed after incubation, using Lugol's solution since this causes less damage to the microalgae than other usual preservatives (Silver \& Davoll 1978). The top $1 \mathrm{~cm}$ of sediment and the overlying water were removed from the corers, and kept in cold $\left(4{ }^{\circ} \mathrm{C}\right)$ and darkness in $50 \mathrm{ml}$ centrifuge plastic tubes, to be processed by radioassay. The samples were washed 4 times with $2 \% \mathrm{HCl}$, and centrifuged for $10 \mathrm{~min}$ at $2000 \mathrm{~g}$ after each wash (Matheke \& Horner 1974). They were then prepared for counting by the technique developed by Van Raalte et al. (1974).

One light and 1 dark corer were also used to separate the 2 fractions of the benthic microflora: epipelic (freeliving) and epipsammic (attached to sand grains). Sep- aration took place after incubation of the intact corers, following Hickman's (1969) procedure, by successive swirling and decantation. Microscopical checking showed small epipsammic diatoms attached to very fine sediment particles, remaining in suspension for a long time, thus their separation from the non-attached fraction was incomplete, and this may have led to a significant overestimation of the epipelic production.

Intact sediment samples for high tide production were taken just before the sediment was covered by the flood tide. Each corer was used as an incubation chamber, and the incubation followed the process described for low-tide samples. The corers were placed on a tray, submerged to approximately $1 \mathrm{~m}$ depth. During incubation, the depth of the samples increased to $2 \mathrm{~m}$, representing average high tide conditions since mean tidal range at the sampling site is around $3 \mathrm{~m}$. The incubations took place from $1300 \mathrm{~h}$ to $1500 \mathrm{~h}$. After incubation, the tray with the samples was retrieved by a rope from land, and the samples were processed as for those of low tide.

Primary production in the water column was measured using 2 pairs of light and dark bottles, hung at the surface and at $0.5 \mathrm{~m}$ depth respectively. The bottles were incubated with $1 \mu \mathrm{Ci}$ of ${ }^{14} \mathrm{C}-\mathrm{NaHCO}$ for $2 \mathrm{~h}$. The samples were then filtered through $0.45 \mu \mathrm{m}$ Millipore filters, which were not dried since desiccation causes loss of radioactivity (Wallen \& Geen 1968). A scintillation cocktail specific for aqueous samples was used. All countings for ${ }^{14} \mathrm{C}$ uptake measurements were made by a Packard Tri-Carb Model 2009 liquid scintillation spectrometer.

Five replicate sediment cores ( $4 \mathrm{~cm}$ I.D.) per sample were taken for pigment analysis. This number of replicates accounts for the 'area minima' and was a result of our preliminary study on spatial heterogeneity (Fig. 2).

The top centimeter of each core was kept for quantitative analysis, since most of the total pigments in the



Fig. 1. Map of Ria de Arosa, NW Spain. Circle indicates the sampling site 


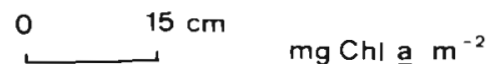

A
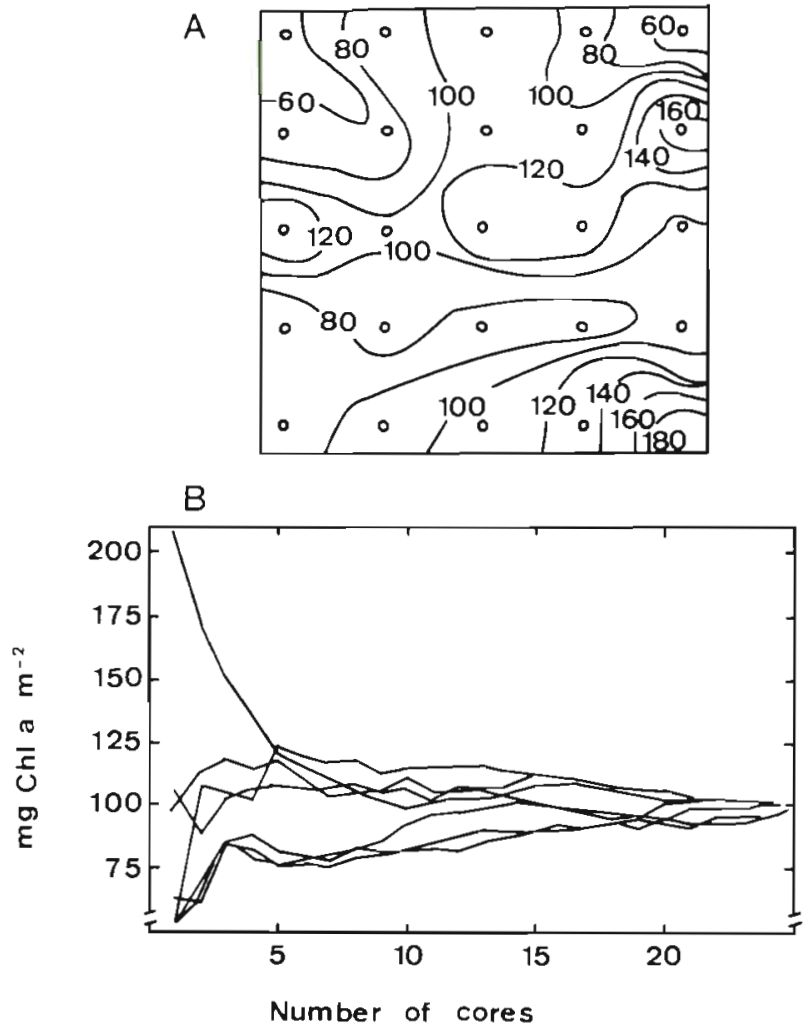

Fig. 2. (A) Spatial heterogeneity of chlorophyll in the top centimeter of sediment. Circles show sampling points. (B) Relation between number of cores and estimated chlorophyll a concentration $\mathrm{m}^{-2}$. Derived from (A) by random combination of increasing number of cores. Five cores seems to be the minimum to smooth out individual core variation, giving a consistent average

sediment are usually here (Leach 1970, Cadee \& Hegeman 1974, Riznyk et al. 1978). The pigments were extracted with $90 \%$ acetone in cold $\left(4^{\circ} \mathrm{C}\right)$ and darkness for $24 \mathrm{~h}$, and subsequently centrifuged for $10 \mathrm{~min}$. The quantitative analysis followed the methods of Lorenzen (1967) and Whitney \& Darley (1979). The combination of both methods allowed differentiation of chlorophyll a from chlorophyllide $a$ as well as phaeophytine a from phaeophorbide $a$. The use of $\mathrm{MgCO}_{3}$ was avoided, since it may prevent the complete phaeophytinization of the acidified extracts (Moed \& Hallegraeff 1978) and tends to absorb significant quantities of chlorophyllide $a$ and phaeophorbide $a$.

Pigment analysis of the water column was carried out by filtering 0.5 to $1.5 \mathrm{l}$ samples of seawater through Whatman GF/C glass-fiber filters. These filters were processed as for sediment samples.

Organic matter content of the top centimeter of sediment was measured as weight loss by ignition, by ashing $\left(550^{\circ} \mathrm{C}, 5\right.$ to $\left.6 \mathrm{~h}\right)$ the oven-dried sediment. Three replicates per sample were used.

Carbon and nitrogen contents of the top centimeter of sediment were measured with a Perkin Elmer $240 \mathrm{CNH}$, at $740^{\circ} \mathrm{C}$, from 3 replicate cores per sample. The temperature used avoided carbonate interference (Telek \& Marshall 1974) and was sufficient for quantitative analysis (Gordon \& Sutcliffe 1973). C and N measurements in the water column were made by filtering seawater through Whatman GF/C glass-fiber filters, and processing the filters by the method above.

Nitrate, nitrite, ammonium and orthophosphate concentrations in the water column and in the interstitial water of the sediment were measured by a Technicon autoanalyzer II.

Solar radiation during incubations was recorded at 5 min intervals, using a Kahl Instruments photometer (Model 268 WA 310). Data on monthly solar radiation, for year-round production estimations, were provided by a nearby meteorological observatory.

Particle-size analysis of the sediments followed the method recommended by the International Biological Programme (Buchanan \& Kain 1971).

\section{RESULTS}

\section{Primary production}

The seasonal pattern of production was similar for flooded (high tide) and exposed (low tide) sediments (Fig. $3 \mathrm{~B}, \mathrm{C}$ ), but mean production was consistently higher under esposed conditions. Carbon uptake was low in winter, increased in spring (the increase being more pronounced in high tide samples), declined in July and August and rose to a high peak in September. From October, production decreased to winter values, except for a high value in November for exposed sediments. The average monthly production rates during 1981 were 10.7 and $23.8 \mathrm{mg} \mathrm{C} \mathrm{m}^{-2} \mathrm{~h}^{-1}$ for flooded and exposed sediments respectively. Primary production in the water column (Fig. 3 A) showed a maximum value in June, and smaller peaks in September and November. The average monthly production was $2.6 \mathrm{~g} \mathrm{C} \mathrm{m}^{-2} \mathrm{~h}^{-1}$.

Monthly values of production showed no significant correlation with total solar radiation received during incubation: $r=0.36$ for the water column, $r=0.47$ for high tide and $\mathrm{r}=0.14$ for low tide $(\mathrm{p}>0.05$ in all cases). Production also showed no correlation with temperature during incubation: $r=0.22$ for the water column, $r=0.4$ for high tide and $r=0.03$ for low tide.

Table 1 shows values of production rates and radiation. Daily production rates were estimated by using the ratio (total daily radiation)/(radiation received du- 


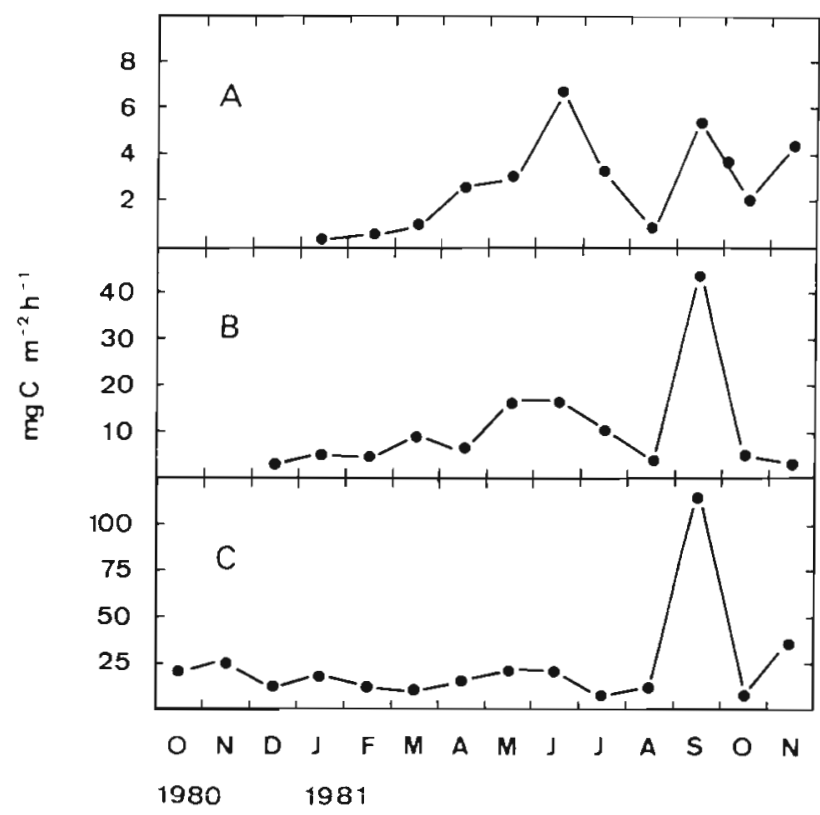

Fig. 3. Primary production of water column (A), and sediment at high tide (B) and low tide (C), during period of sampling

ring incubation) as a day-length factor (Leach 1970). Since production was different for flooded and exposed sediment incubations, an average tidal variation was considered in the computations. Total year-round pro- duction was estimated to be $6 \mathrm{~g} \mathrm{C} \mathrm{m}^{-2}$ for the water column, $25 \mathrm{~g} \mathrm{C} \mathrm{m}^{-2}$ for flooded sediments and $54 \mathrm{~g}$ $\mathrm{C} \mathrm{m}^{-2}$ for exposed sediments. This gives an estimate of $79 \mathrm{~g} \mathrm{C} \mathrm{m}^{-2} \mathrm{yr}^{-1}$ altogether in the sediments, and a total production for the intertidal area studied of $85 \mathrm{~g}$ $\mathrm{Cm}^{-2} \mathrm{yr}^{-1}$.

\section{Pigment analysis}

Seasonal variation of the chlorophyll $a$ and phaeophytine a content of the water column is shown in Fig. $4 \mathrm{~A}, \mathrm{C}$. Chlorophyll a reached 2 maximum values, in April and in November, following the characteristic spring and fall blooms of phytoplankton. How ever, the seasonal variation of phaeophytine is more irregular and, in general, appears to be related to the abundance of this pigment in the sediment (Fig. 4 D).

The chlorophyll a content of the sediment remained rather constant, with no clear pattern of seasonal variatıon, although higher values were found in December, March, July and October (Fig. 4 B). These variations are more than likely a result of no more than sampling or experimental errors

The values shown are for total chlorophyll $a$, including both active and degraded forms. In the sediments, the active form comprised 10 to $20 \%$ of the total chlorophyll (with a mean value of $15 \%$ ), chlorophyl-

Table 1. Mean monthly primary production for water column and sediment, and estimated annual production of intertidal area at Carril

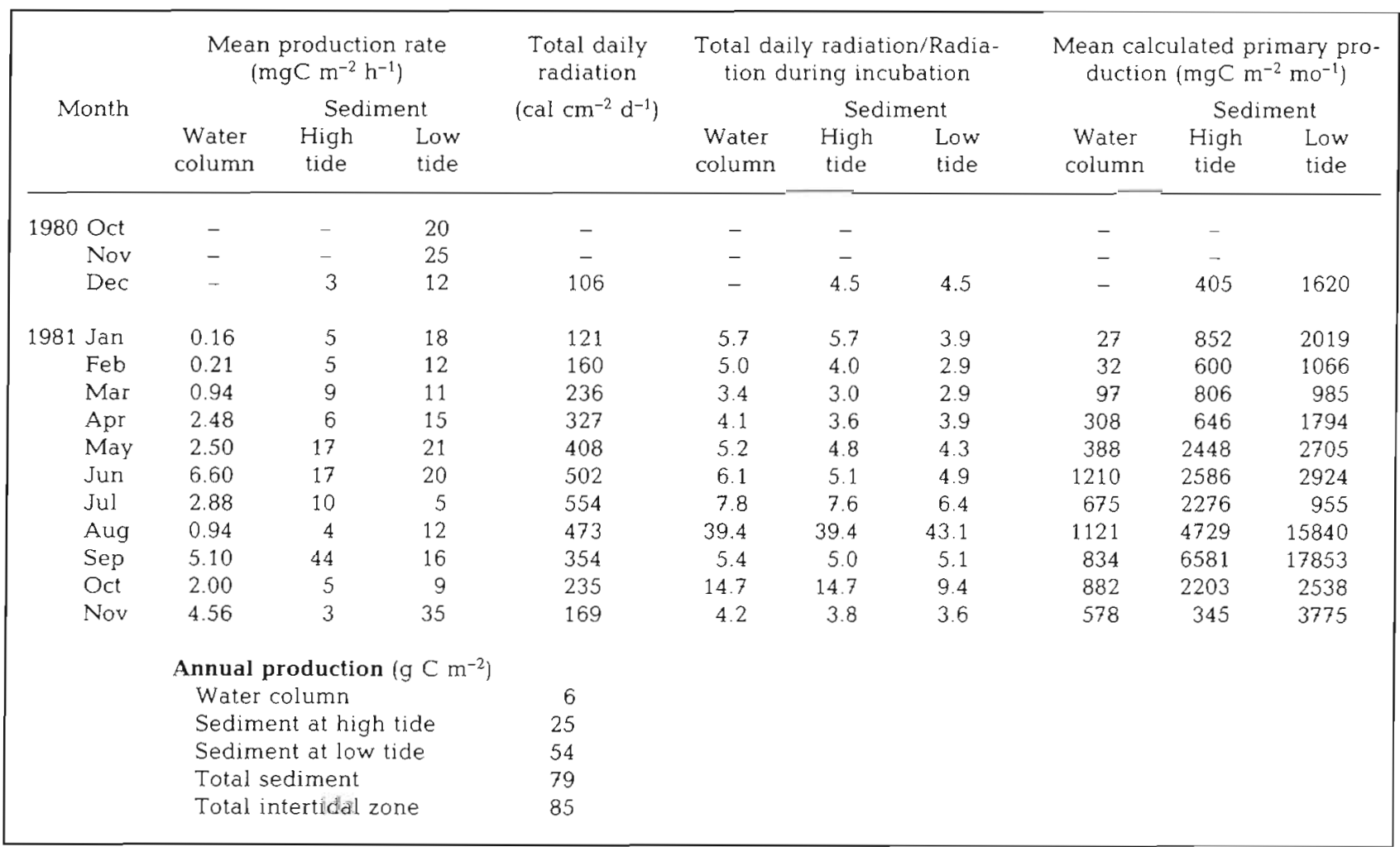




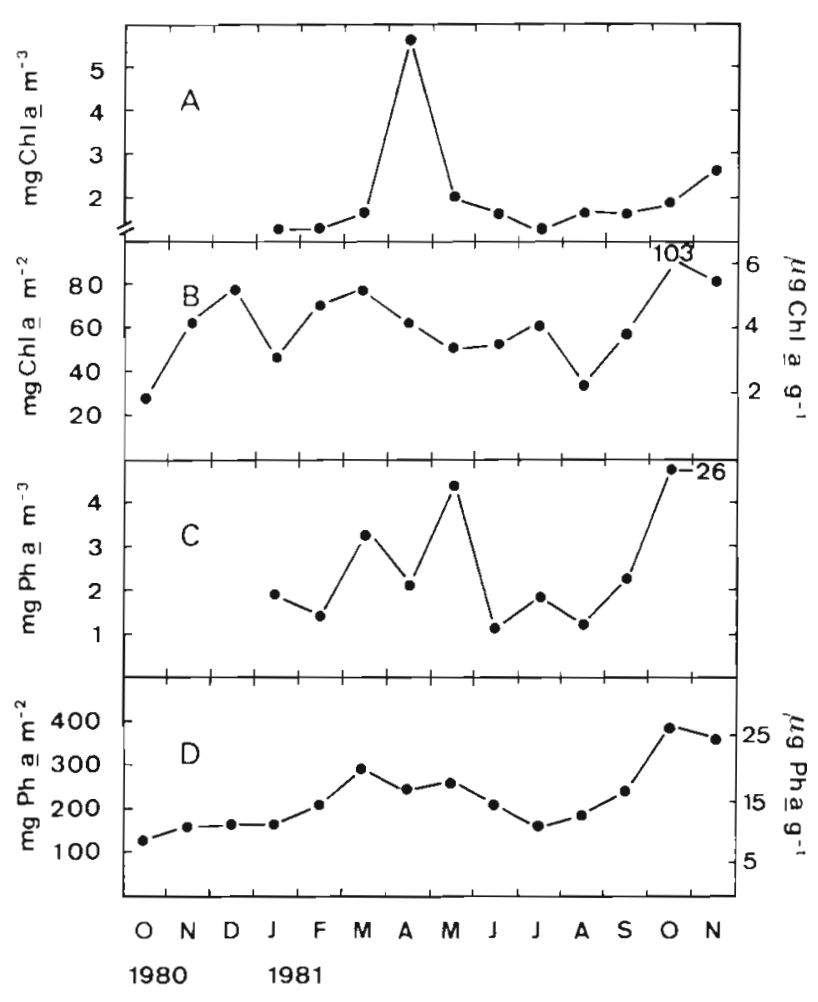

Fig. 4. Concentration of chlorophyll $a$ and phaeopigments in the water column ( $A$ and $C$ ), and top centimeter of sediment (B and D). Values of pigment in sediments are expressed both as $\mathrm{mg}$ pigment $\mathrm{m}^{-2}$ and as $\mu \mathrm{g}$ pigment $\mathrm{g}^{-1}$ dry sediment

lide comprised 5 to $22 \%$ (mean $13 \%$ ), phaeophytine 43 to $61 \%$ (mean $54 \%$ ) and phaeophorbide 15 to $23 \%$ (mean $19 \%$ ). Thus, $85 \%$ of the chlorophyll a in the sediments corresponded to degraded forms. These values are close to those found in the water column, where active chlorophyll accounts for 4 to $36 \%$ (mean $18 \%$ ) of the total chlorophyll.

The maximum chlorophyll content was found in the top $2 \mathrm{~cm}$ of the sediment (Fig. $5 \mathrm{~A}$ ), although small amounts of active chlorophyll were found as deep as $7 \mathrm{~cm}$ into the sediment.

We have assumed a carbon to chlorophyll ratio of 100 for standing crop estimations from chlorophyll data. This ratio gives microalgal standing crops corresponding to 1.5 to $6 \%$ of the total carbon in the top centimeter of the sediment. Thus, the remaining 94 to $98 \%$ of the organic carbon is detrital. In the water column, the microalgal carbon accounts for 6 to $19 \%$ of the total carbon. The values of the ratios chlorophyll al total carbon, chlorophyll a/organic matter, and $665 \sigma^{\prime}$ 665 (the ratio of unacidified to acidified pigment measured at $665 \mathrm{~nm}$ ) were very low for both water column and sediment: the ratio $\mathrm{Chl}$ a/C ranged from $1.5 \times 10^{-4}$ to $6.2 \times 10^{-4}$ in the sediment and from $5.6 \times 10^{-4}$ to $1.89 \times 10^{-3}$ in the water column. Clearly, most of the carbon is detrital.

\section{Organic matter, carbon and nitrogen}

Carbon and nitrogen content of the water column throughout the year averaged $2,000 \pm 1,120 \mathrm{mg} \mathrm{m}^{-3}$ and $210 \pm 122 \mathrm{mg} \mathrm{m}^{-3}$ respectively. Seasonal patterns of variation were similar for $C$ and $N$, with 2 maximum values, in April and November, and lowest values in summer. This variation is similar to that observed for chlorophyll a (Fig. 4 A). The C/N ratio ranged from 8 to 10, with higher values in March, July and October,

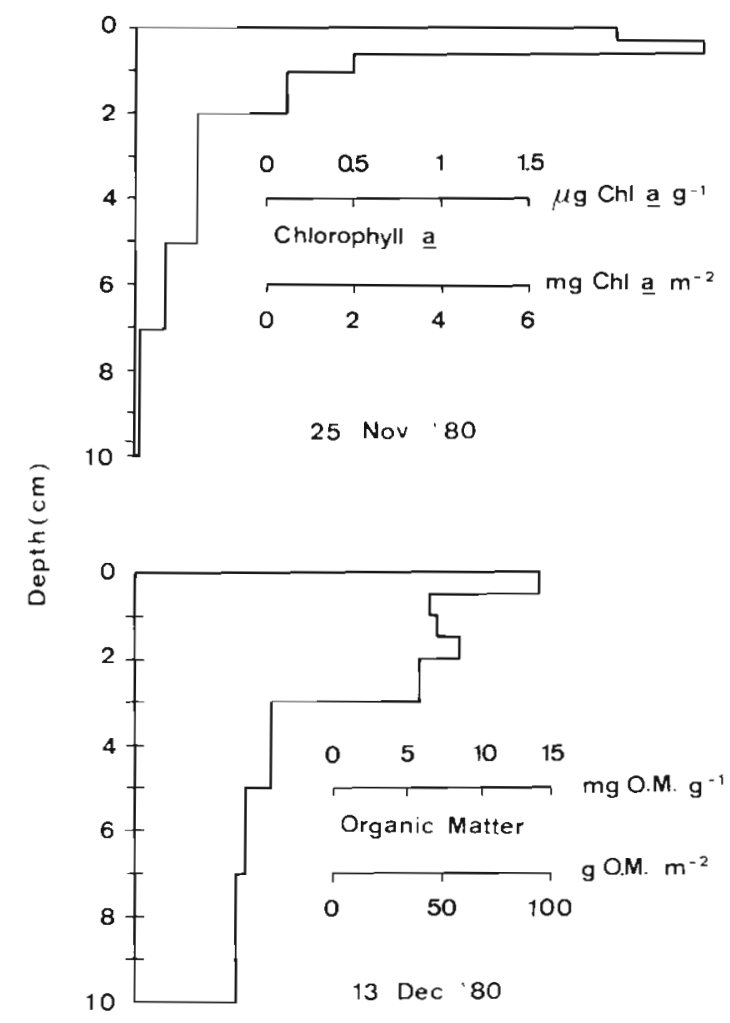

Fig. 5. Profiles of mean functional chlorophyll a and organic matter in the upper $10 \mathrm{~cm}$ of sediment

with no significative correlation $(r=0.38)$ with periods of rapid algal growth, so the meaning of this variation remains rather obscure.

The organic matter (OM) content of the sediment varied between 250 and $400 \mathrm{~g} \mathrm{OM} \mathrm{m}^{-2}$, with little seasonal variation except for a maximum value in November 1980 and a minimum value in January 1981 , although these values are likely to be due to sampling error. The carbon and nitrogen content of sediment throughout the year averaged $150 \pm 39 \mathrm{~g} \mathrm{C} \mathrm{m}^{-2}$ and $15 \pm 4 \mathrm{~g} \mathrm{~N} \mathrm{~m}^{-2}$ respectively. The $\mathrm{C} / \mathrm{N}$ ratio varied between 5 and 15, and showed no clear relation with algal growth. The vertical profile of organic matter in the sediment (Fig. $5 \mathrm{~B}$ ) shows that $60 \%$ of the organic matter is concentrated in the top $3 \mathrm{~cm}$. 


\section{Nutrients}

Fig. 6 shows orthophosphate, nitrate, and nitrite concentrations in the water column and in the interstitial water of the sediment. Amonium values, not plotted, remained consistently above $10 \mu \mathrm{g}$-at $\mathrm{N}-\mathrm{NH}_{4}^{+} \mathrm{l}^{-1}$. These values suggest that there should not be nutrient limitation for microalgal growth in the sediment.

\section{Vertical migration}

Fig. 7 shows a small variation in the vertical distribution of chlorophyll as a function of tidal variation. This suggests a higher proportion of epipsammic (attached to sand grains) over epipelic (free-living) microflora, since the former cannot migrate vertically.

\section{DISCUSSION}

The estimated annual primary production of the benthic microalgae, $79 \mathrm{~g} \mathrm{C} \mathrm{m}^{-2}$, is a moderate value compared to other areas (see Table 2). However, it has to be taken cautiously. The high value found in September (Fig. 3) appears to be abnormal, but careful examination of the solar radiation values suggest that September production is not abnormally high; rather that August and October productions are abnormally low. Total radiation received during incubation in August and October was only 11 and $25 \mathrm{cal} \mathrm{cm}^{-2}$ due to heavy cloud coverage, when the expected radiation

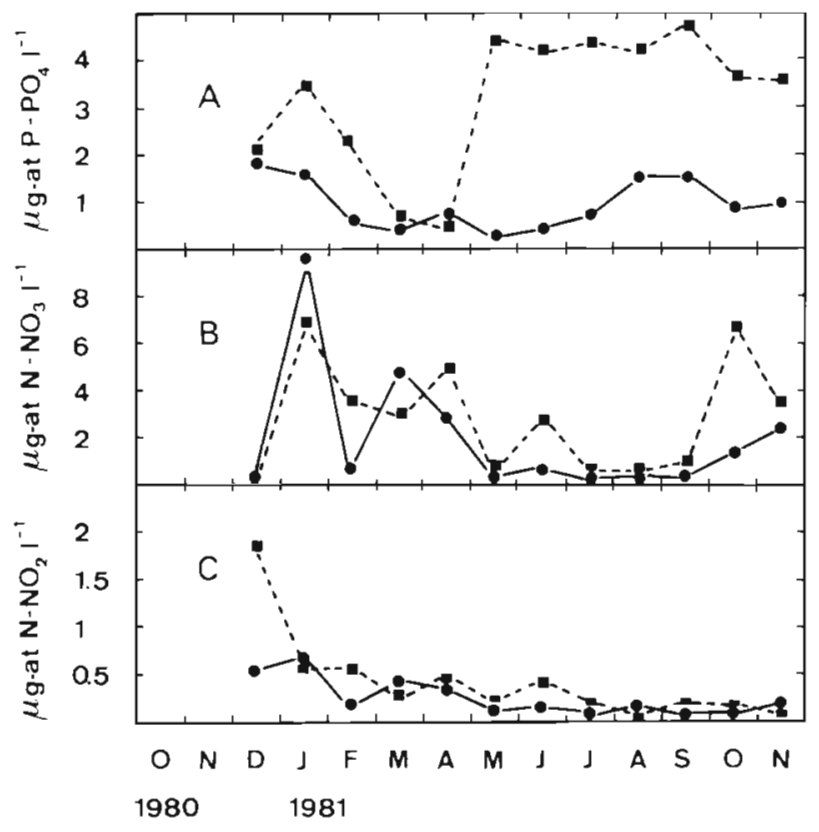

Fig. 6. Monthly values of phosphate, nitrate and nitrite in water column (solid line) and interstitial water of sediment (dashed line)

from monthly averaged radiation was 95 and $47 \mathrm{cal} \mathrm{cm}^{-2}$ respectively. On the other hand, total radiation received during incubation in September was $69 \mathrm{cal} \mathrm{cm}^{-2}$, very close to the expected value of $71 \mathrm{cal}$ $\mathrm{cm}^{-2}$. Thus, we can consider August and October values to be closer to that obtained for September and, consequently, a peak of production for these 3 mo could reasonably be expected. Comparison with other

Table 2. Comparison of annual in situ production values of epibenthic microalgae

\begin{tabular}{|c|c|c|}
\hline Source & $\begin{array}{l}\text { Annual production } \\
\left(\mathrm{gC} \mathrm{m}^{-2} \mathrm{yr}^{-1}\right)\end{array}$ & Area \\
\hline Pomeroy (1959) ${ }^{*}$ & 200 & Duplin River Estuary, Georgia \\
\hline Pomeroy $(1960)^{\circ}$ & 213 & Boca Ciega Bay, Florida \\
\hline Grontved $(1960)^{\cdots}$ & 116 & Danish fjords \\
\hline Pamatmat (1968) & $143-226$ & Puget Sound, Washington \\
\hline Steele \& Baird (1968) & $4-9$ & Loch Ewe Bay, Scotland \\
\hline Hargrave $(1969)^{\circ}$ & 40 & Marion Lake, B. C. Canada \\
\hline Leach $(1970)$ & 31 & Ythan Estuary, Scotland \\
\hline Marshall et al. (1971) & 81 & New England estuaries \\
\hline Bunt et al. (1972) & $11-60$ & Florida and Jamaica estuaries \\
\hline Matheke \& Horner (1974) & 5 & Chukchi Sea, Alaska \\
\hline Cadee \& Hegeman (1974) " & 101 & Dutch Wadden Sea \\
\hline Van Raalte et al. (1976) & 105 & Massachusetts salt marsh \\
\hline Cadee \& Hegeman (1977) & 85 & Dutch Wadden Sea \\
\hline Riznyk et al. (1978) & $115-246$ & Bolsa Bay, California \\
\hline Joint (1978) & 143 & Lynher Estuary, England \\
\hline Present study & 79 & Ria de Arosa, NW Spain \\
\hline $\begin{array}{l}\text { - Oxygen method } \\
\text { Altered samples }\end{array}$ & & \\
\hline
\end{tabular}


data is restricted by the wide variability of procedures used: different methods $\left(\mathrm{O}_{2},{ }^{14} \mathrm{C}\right)$, treatments of samples (intact, altered) preservatives (buffered formalin, Lugol's solution, $\mathrm{H}_{3} \mathrm{PO}_{4}$ ), sample processing for ${ }^{14} \mathrm{C}$ uptake determinations (wet digestion, combustion), and measurements of radioactivity (Geiger-Muller, LSC). In some cases, only low-tide production values were used for day-long integrations, thus clearly overestimating total daily production.

An important part of the production was measured during high tide: around $30 \%$ of total production in the sediment took place during high tide. This proportion, however, can be very variable: Leach (1970) found similar results, whereas Joint (1978) found no production during high tide. Particle size of sediment, along with water turbulence, are considered the main factors controlling high-tide production. In sandy sediments, such as those studied here, an important fraction of the cells are attached to the sand grains (epipsammic fraction). This non-motile flora does not migrate vertically in the sediment as a function of tidal variation (Leach 1970). Thus they remain at the surface of the sediment during flood tide, photosynthesizing. In our case, the coarse nature of the sediment suggested a high proportion of epipsammic flora. This was confirmed by the small amount of vertical migration observed (Fig. 7), and supported by the production data mentioned. Microscopical observation also showed small diatoms attached to the sand grains. When the sediment is exposed, both fractions, attached (epipsammic) and free-living (epipelic), photosynthesize but, during flood tide, the epipelic flora moves down into the sediment and production is carried out only by the epipsammic fraction. In our case, $60 \%$ of the low-tide production was due to the epipsammic fraction, but this percentage increased to $75 \%$ during high tide. However, these proportions are probably underestimates of the total production accounted for by epipsammic cells, due to the low accuracy of the separation methods available.

Epibenthic production $\mathrm{m}^{-2}$ was about 10 -fold greater than that of phytoplankton in the water column. Cadee \& Hegeman (1974) found similar results, while Matheke \& Horner (1974) found epibenthic production to be only twice as high as that of phytoplankton. In any case, microscopical observation showed a generally important number of benthic cells resuspended in the water column, thus accounting for a significant proportion of the measured phytoplanktonic production. This suggests that benthic microalgae can be a major food source for bivalves, although the proportion should be determined by gut-content analysis, since phytoplankton, although lower in production $\mathrm{m}^{-2}$, can be available to filter feeders in much higher amounts due to the continuous movement of the water masses.

The main factor controlling production and distribution of microbenthic algae is thought to be disturbance of the sediment. Human activity (culture and collection of clams and cockles) along with the combination of waves, wind and tides, cause an almost permanent disturbance of the upper layers of the sediment. This physical removal has been recognized as an important limiting factor for microalgal production (Riznyk et al. 1978). In addition, sand extractions are made in a nearby area, thus resuspending amounts of fine material which is partially deposited on the sediment surface, shadowing the microflora. This shadowing effect is thought to reduce production substantially, since a high proportion of the flora belongs to non-motile forms, incapable of moving upward through the newly deposited material. The resuspension of this fine material can also limit production of the water column since it decreases penetration of light.

Functional chlorophyll was found down to $7 \mathrm{crn}$ into

Fig. 7. Vertical migration of benthic microflora into the sediment in relation to tidal water

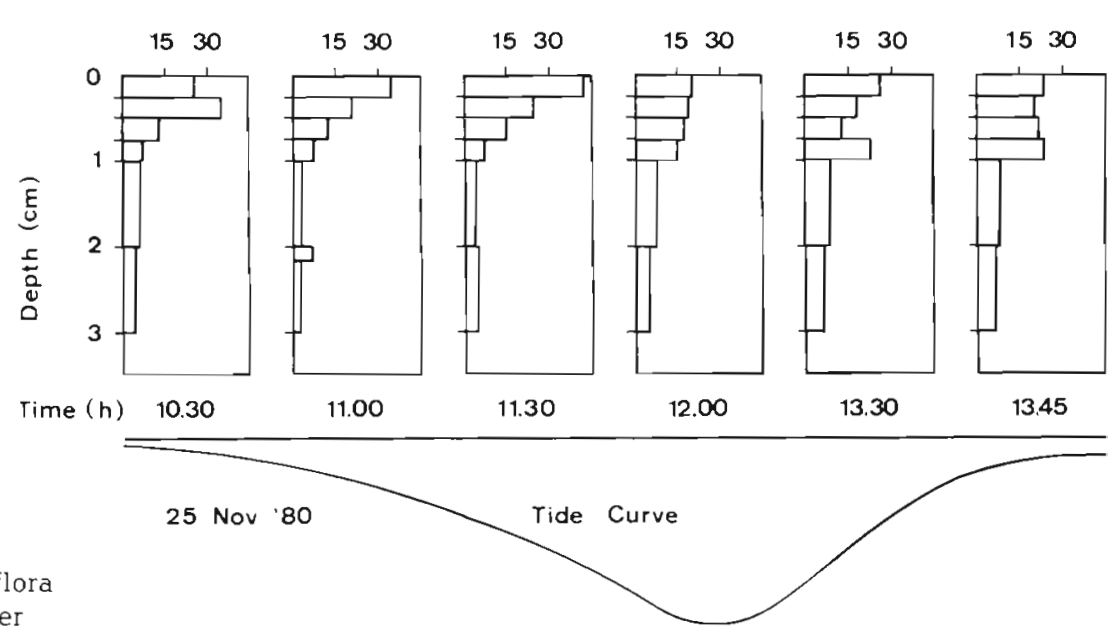


the sediment. Similar depths were found in other studies (Meadows \& Anderson 1968, Steele \& Baird 1968, Leach 1970, Joint 1978). This burial of active chlorophyll could be explained by the sediment disturbance mentioned above, and also by the drainage of pore water through the sediment during low tide which could drag down microalgal cells. Total chlorophyll values in the sediment were lower than those obtained by Leach (1970) and Joint (1978), and close to those of Cadee \& Hegeman (1977). These relatively low values are probably a consequence of the sandy composition of the sediment, and of the method used in our case, which only measures functional (active) chlorophyll.

The decrease of sediment carbon content during summer can be related to the increase of bacterial activity and subsequent decomposition of organic matter. The density of deposit-feeding worms (such as Arenicola, Hydrobia) also increases in summer (Gonzalez pers. comm.). However, grazing by these invertebrates does not usually cause an important variation in the carbon content of the sediment (Newell 1965). On the other hand, the feeding activity of filter-feeders (clams, cockles), very abundant during summer, might account for the decrease in carbon content, by filtering resuspended cells and detritus.

Nutrient concentrations in the interstitial water of the sediment were relatively low, compared to values reported in other areas (Riznyk et al. 1978), except for ammonium, which is very abundant throughout the year. Nutrient limitation may not occur due to the high ammonium concentration and the possibly high organic phosphorus concentration, that can readily produce assimilable phosphate (Wetzel 1975). The increase in the sediment nitrogen content during summer did not correspond to an increase in microalgal biomass. Joint (1978) found similar results, and explained this increase in $\mathrm{N}$ as a result of the development of heterotrophic organisms since chlorophyll was used to estimate microalgal biomass. Nutrient concentrations showed no correlation with algal growth, and this supports the idea that there is no nutrient limitation, and that autochthonous regeneration of nutrients is perhaps less important, as a nutrient source, than allochthonous supply from rivers, runoff from the land, and local upwellings (Riznyk et al. 1978). Similarly, this allochthonous supply obscures any correlation of $\mathrm{C}, \mathrm{N}$ and $\mathrm{C} / \mathrm{N}$ of the sediment with algal growth.

The occurrence of active chlorophyll $a$ in deep layers of the sediment could be explained by admitting the capability of heterotrophic assimilation by these algae. Such capability has been reported by several authors: Lewin \& Lewin (1960), Homer \& Alexander (1972), Ukeles \& Rose (1976), Darley et al. (1979) in different algae. The high detritial content of the sediment could allow, and even enhance, heterotrophic metabolism. In fact, Hellebust \& Lewin (1977) found an increase in the heterotrophic activity of diatoms when organic matter concentration was high. Moreover, bacteria in natural waters keep concentrations of solutes at a low level, thus limiting heterotrophy of algae (Hobbie \& Wright 1965). However, in sediments, the high amount of undegraded organic matter could allow unlimited heterotrophy. Clearly, the study of heterotrophy should be included in microbenthic surveys in the future.

There are no data yet available on microalgal respiration. However, Pamatmat (1968) found sediment respiration values in the range 0.5 to $67 \mathrm{mg} \mathrm{C} \mathrm{m}^{-2} \mathrm{~h}^{-1}$ in intertidal areas. The rate of production in these

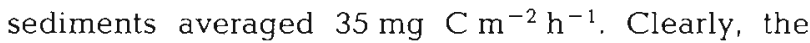
study of respiration is critical in microbenthic studies.

There are also no data available on secondary production, but the large yield of clams and cockles, as well as the abundance of the rest of the infauna (Penas \& Gonzalez 1983) allows us to assume a high secondary production. Thus, the question arises whether the microalgal production is sufficient as a food source for secondary producers, or whether an extra supply of food is necessary. The study of different sources of organic matter is of great importance to understand the dynamics of these intertidal sand flats.

Acknowledgements. This work was carried out with funds from the cooperative Spanish-U.S. program Biological Research in the Galician Rias (N.W. Spain)', No. 0020.

\section{LITERATURE CITED}

Buchanan, J. B., Kain, J. M. (1971). Measurement of the physical and chemical environment. In: Holme, N. A., McInctyre, A. D. (ed.) Methods for the study of marine benthos. Blackwell Scientific Publications, Oxford and Edinburgh, p. 30-58

Bunt, J. S., Lee, C. C., Lee, E. (1972). Primary productivity and related data from tropical and subtropical marine sediments. Mar. Biol. 16: 28-36

Cadee, G. C., Hegeman, J. (1974). Primary production of the benthic microflora living on tidal flats in the Dutch Wadden Sea. Neth. J. Sea Res. 8: 260-291

Cadee, G. C., Hegeman, J. (1977). Distribution of primary production of the benthic microflora and accumulation of organic matter on a tidal flat area, Balgzand, Dutch Wadden Sea. Neth. J. Sea Res, 11:24-41

Darley, W M., Ohlman, C. T., Wimpee, B. B. (1979). Utilization of dissolved organic carbon by natural populations of epibenthic salt marsh diatoms. J. Phycol. 15: 1-5

Gordon, D. C. Jr., Sutcliffe, W. H. Jr. (1973). A new dry combustion method for simuitaneous determination of total organic carbon and nitrogen in seawater. Mar. Chem. 1: $231-244$

Grontved, J. (1960). On the productivity of microbenthos and phytoplankton in some Danish Fjords. Meddr. Danm. Fisk.-og Havunders., N.S. 3: 55-92

Hargrave, B. T. (1969). Epibenthic algal production and com 
munity respiration in the sediment of Marion Lake. J. Fish. Res. Bd Can. 26: 2003-2006

Hellebust, J. A., Lewin, J. (1977). Heterotrophic nutrition of diatoms. In: Werner, D. (ed.) Biology of diatoms. Univ. of Calif. Press, Berkeley and Los Angeles, p. 169-197

Hickman, M. (1969). Methods for determining the primary productivity of epipelic and epipsammic algal associations. Limnol. Oceanogr 14: 936-941

Hobbie, J. E., Wright, R. T (1965). Competition between planktonic bacteria and algae for organic solutes. Memorie Ist. Ital. Idrobiol. 18 (Suppl.): 175-185. Also in: Goldman, C. R. (ed.) Primary productivity in aquatic environments. Univ. Calif. Press, Berkeley (1966), p. 175-185

Horner, R., Alexander, V. (1972). Algal populations in arctic sea ice: an investigation of heterotrophy. Limnol. Oceanogr. $17: 454-458$

Joint, I. R. (1978). Microbial production of an estuarine mudflat. Estuar. coast mar. Sci. 7: 185-195

Leach, J. H. (1970). Epibenthic algal production in an intertidal mudflat. Limnol. Oceanogr. 15: 514-521

Lewin, J. C., Lewin, R. A. (1960). Autotrophy and heterotrophy in marine littoral diatoms. Can. J. Microbiol. 6: $127-134$

Lorenzen, C. J. (1967). Determination of chlorophyll and phaeopigments: spectrophotometric equations. Limnol. Oceanogr 12: 343-346

Maciolek, J. A. (1963). Pressure filtration apparatus. Limnol. Oceanogr. 8: 301-302

Marshall, N., Oviatt, C. A., Skauen, D. M. (1971). Productivity of the benthic microflora of shoal estuarine environments in southern New England. Int. Revue ges. Hydrobiol. 56 $947-956$

Marshall, N., Skauen, D. M., Lampe, H. C., Oviatt, C. A. (1973). Primary production of benthic microflora. In: A guide to the measurement of marine primary production under some special conditions. UNESCO Monographs on oceanographic methodology 3: 37-44

Matheke, G. E. M., Horner, R. (1974). Primary productivity of the benthic microalga in the Chukchi Sea near Barrow Alaska. J. Fish. Res. Bd Can. 31: 1779-1786

Meadows, P. S., Anderson, J. G. (1968). Microorganisms attached to marine sand grains. J. mar biol. Ass. U.K. 48: 161-175

Moed, J. R., Hallegraeff, G. M. (1978). Some problems in the estimation of chlorophyll-a and phaeopigments from preand post-acidification spectrophotometric measurements Int. Revue ges. Hydrobiol. 63: 787-800

Newell, R. (1965). The role of detritus in the nutrition of the marine deposit feeders, the Prosobranch Hydrobia ulvae and the bivalve Macoma balthica. Proc. zool. Soc. Lond. 144: $25-45$

Nunes, M. T., Marino, J., Iglesias, M. L., Gonzalez, N., Campos, M. J., Cabanas, J. M. (1984). Condiciones ambientales, produccion primaria y sucesion de especies fitoplanctonicas en la Ria de Arousa (NW de Espana). Cuad. da Area Ci. Mar, Seminario de Estudos Galegos 1: 163-172. Ediciones do Castro, O Castro-Sada, La Coruña

Pamatmat, M. M. (1968). Ecology and metabolism of a benthic community on an intertidal sandflat. Int. Revue ges. Hydrobiol. 53: 211-298

Penas, E., Gonzalez, G. (1983). Relationships between benthic infauna and environmental factors in three beaches of the
Ria de Arosa embayment (Spain) using canonical correlation analysis. J. exp. mar. Biol. Ecol. 68: 245-256

Penas, E. (1984). Modelos de simulacion de ecosistemas: el caso de la Ria de Arosa. Inf. Tec. 10

Pomeroy, L. R. (1959). Algal productivity in salt marshes of Georgia. Limnol. Oceanogr. 4: 386-397

Pomeroy, L. R. (1960). Primary productivity off Boca Ciega Bay, Florida. Bull. Mar. Sci. Gulf. Caribb. 10: 1-10

Riznyk, R. Z., Edens, J. I., Libby, R. C. (1978). Production of epibenthic diatoms in a southern California impounded estuary. J. Phycol. 14: 273-279

Silver, M. W., Davoll, P. J. (1978). Loss of $14-\mathrm{C}$ activity after chemical fixation of phytoplankton: error source for autoradiography and other productivity measurements. Lim. nol. Oceanogr. 23: 362-368

Stanley, D. W. (1971). A method for measuring the productivity of benthic microalgae. M.S. thesis. North Carolina State Univ., Raleigh, N.C., p. 1-34

Steele, J. H., Baird, I. E. (1968). Production ecology of a sandy beach. Limnol. Oceanogr. 13: 14-25

Telek, G., Marshall, N. (1974). Using a CHN analyzer to reduce carbonate interference in particulate organic carbon analyses. Mar. Biol. 24: 219-221

Tenore, K. R., Gonzalez, N. (1975). Food chain patterns in the Ria de Arosa, NW Spain: an area of intense mussel aquaculture. In: Persoone, G., Jaspers, E. (ed.) Proc. 10th Eur. mar. Biol. Symp. 2: 601-619. Universa Press, Wetteren, Belgium

Tenore, K. R., Boyer, L. F., Cal, R. M., Corral, J., GarciaFernandez, C., Gonzalez, N., Gonzalez-Gurriaran, E. Hanson, R. B., Iglesias, J., Krom, M., Lopez-Jamar, E., McClain, J., Pamatmat, M. M., Perez, A., Rhoads, D. C., de Santiago, G., Tietjen, J., Westrich, J., Windom, H. L. (1982). Coastal upwelling in the Rias Bajas, NW Spain: Contrasting the benthic regimes of the Rias de Arosa and de Muros. J. mar Res, 40: 701-772

Ukeles, R., Rose, W. E. (1976). Observations on organic carbon utilization by photosynthetic marine microalgae. Mar. Biol. 37: 11-28

Van Raalte, C., Stewart, W. C., Valiela, I., Carpenter, E. J. (1974). A 14-C technique for measuring algal productivity in salt marsh muds. Botanical mar. 17: 186-188

Van Raalte, C., Valiela, I., Teal, J. M. (1976). Production of epibenthic salt marsh algae: light and nutrient limitation. Limnol. Oceanogr. 21: 862-872

Varela, M., Fuentes, J. M., Penas, E., Cabanas, J M. (1984) Produccion primaria de las Rias Baixas de Galicia. Cuad. da Area Ci. Mar., Seminario de Estudos Galegos 1: 173-182. Ediciones do Castro, O Castro-Sada, La Coruna

Wallen, D. G., Geen, G. H. (1968). Loss of radioactivity during storage of 14-C labelled phytoplankton on membrane filters. J. Fish. Res. Bd Can. 25: 2219-2224

Wetzel, R. G. (1964). A comparative study of the primary productivity of higher aquatic plants, periphyton, and phytoplankton in a large shallow lake. Int. Revue ges. Hydrobiol. 49: 1-61

Wetzel, R. G. (1975). Limnology. W. B. Saunders Co., Philadelphia

Whitney, D. E., Darley, W. M. (1979). A method for the determination of chlorophyll-a in samples containing degradation products. Limnol. Oceanogr. 24: 183-186 